\title{
Demographics, Economics and Psychographics Determinants of Life Insurance Consumption among School Teachers in Kampar, Perak
}

\author{
Juliana Abu Bakar*a, Thavamalar ap Ganapathy ${ }^{\mathrm{b}}$, Chitrah a/p Krishnan ${ }^{\mathrm{c}}$ \\ Universiti Tunku Abdul Rahman (Author a) \\ Universiti Tunku Abdul Rahman (Author b) \\ Universiti Tunku Abdul Rahman (Author c) \\ *Corresponding author Email: juliana@utar.edu.my
}

\begin{abstract}
Life insurance has become a stable and progressive market keep improving as one of the key financial pillars in Malaysia. However, current consumption rate of $55.5 \%$ is considered low and there were more prospects for life insurance companies to grow in suburban and rural areas as the concentration now is more in urban areas. Thereby, there is a need to extend and focus on the rest of uninsured population at which high proportion to be concentrated on both suburban and rural areas. This study aims to determine demographics, economics and psychographics factors that influence consumer purchasing decisions of life insurance among 1,256 school teachers in Kampar district. The stratified random sampling technique applied in order to select the respondents for this study and the data has been analyzed by using multiple regression model. The justification for selecting this technique is to ensure that all schools in Kampar district have its representative. This study found that personality behavior in psychographic factor is positively and significant determinant of life insurance consumption among school teachers in Kampar District. This study will significant towards growth of insurance industry, whereby it wills benefits governmental or non-governmental agencies.
\end{abstract}

Keywords: Demographic; Economic; Psychographics; Life Insurance; School Teachers

\section{Introduction}

Currently, life insurance provides insurance protection to $55.5 \%$ over 30 million of Malaysian population (LIAM, 2015). However, this figure is still far below the government's targeted level to achieve at least $75 \%$ of all Malaysians to be insured by year 2020 . As reported in Financial Stability and Payment Systems (FSPSR), life insurance industry for 2014 recorded a $6.9 \%$ growth in insurance protection to RM1.17 trillion compared to the previous year. Life insurance protection already covers 12.4 million lives, but there still a huge protection gap for household with life insurance on average, the gap ranges around RM100,000 to RM150,000. This amount is below the amount needed to support their family member in the situation of death or disability of the breadwinner (LIAM, 2013). Life insurance industry continued to achieve strong growth in the first three quarters of 2016, $18.3 \%$ growth in new business compared to the same period in 2015.The Takaful sector continued to record higher growth than the conventional sector, $9.8 \%$ and $8.2 \%$ growth rate respectively. The strong performance in this industry as it is currently undergoing a transformation process following the implementation of the Life Insurance and Family Takaful Framework (LIFE Framework), which was enforced on $23^{\text {rd }}$ November 2015. It is also becoming one of the fastest emerging life insurance segments in the Asia-Pacific region. The key factors contributed to this achievement are discipline among individuals towards saving, rising level of consumer confidence and incentive given by government on tax relief. There may be several factors to influence an individual to purchase life insurance poli- cies which are quite unknown or unexplored. In this context, it becomes important to understand the factors influencing the purchase decision by consumers' specifically targeted suburban area. The study of different contributing factors on consumer purchase decision assumes to be significant to the life insurance companies. It is also relevant to governmental/non-governmental agencies, as it appears as a guideline in achieving the $75 \%$ targeted level.

Goods and Services Tax (GST) is a multi-stage tax on domestic consumption and will be charged on all taxable supplies of goods and services in Malaysia except those specifically exempted. In Malaysia, those are registered under the GST Act 2014 is known as a 'registered person' eligible to imposed GST on their products or services and they are allowed to claim back. Therefore, the tax itself is not a cost to the middle person and it will not consider as an expense item in their financial statement. Premium paid for all insurance policies/riders provide coverage on life is exempted from GST. There will be no additional charge to insurance premium, however premium for all non-life insurance and supplementary non-life riders attached to life policies such as personal accident, medical \& health and critical illness without death benefit are not exempted and thus subject to GST. Any fee and charged imposed on these policies are also subject to GST (LIAM, 2015).

Teacher is a group of civil servant with 421,828 teachers servicing in 10180 schools in Malaysia (Ministry of Education Malaysia, 2016). In this study, we focus on 1256 school teachers from 37 schools located in Kampar district, Perak, Malaysia. Undoubtedly, it brings a lot of benefits to the civil servants in terms of house 
loans and family healthcare which certainly could be benefitted after retirement. But, the attractive remuneration and benefits in the public sector have come at a price for the country; one that Malaysia will not be able to afford it in the future. In fact, some believe that it can cause the deterioration of Malaysia's economic growth. It has been recounted that it will now cost the country more than $40 \%$ of government revenue to maintain the public sector, including healthcare benefit. With 1.6 million civil servants in Malaysia, expert has pointed to its sheer size as a reason for the expanding bill of the public service. As Malaysia is transforming to be a high income and developed nation, the demand for better healthcare will grow stronger. Improvement in longevity and advancement in medical technology will further drive up the healthcare cost of the country. This medical inflation will be a burden to the government if the employees in the civil sector continue to depend heavily on government's funding. It is important that Malaysian start to embark on financial planning for their families.

The survey done by LIAM has found that one of the main reasons that Malaysian delay buying life insurance is that they cannot decide how much and which type of life insurance they should buy. From previous statements regarding the trends in life insurance protection, with only $55.5 \%$ from total 30 million populations in Malaysia, it is clear that many households have no life insurance. Thus, this study aims to contribute for a better understanding of teacher's decision in purchasing life insurance by using demographic, economics and psychographics characteristics, in an effort to improve the efficiency of life insurance consumption. This study focused on 1,256 school teachers from Kampar district which is located in the state of Perak Darul Ridzuan, Malaysia.

\subsection{Research Objectives}

The main objective of this study is to determine demographics, economics and psychographics factors that influence purchasing decisions of life insurance among school teachers in Kampar district. The specific objectives of this study are as follow:

a) to identify correlation between demographics (age, gender, number of dependents and education) factors and consumption of life insurance.

b) to identify correlation between economics (income, income tax and GST) factors and consumption of life insurance.

c) to identify correlation between psychographics (personality behavior, lifestyle, value and service experienced) factors and consumption of life insurance.

\section{Literature Review}

\subsection{Demographics Factors}

Demand for any type of life insurance product assumed to be positively related with the higher level of education. As people become more educated, it may increase their capability to realize the benefits of having proper risk management, therefore it will lead to higher demand of life insurance. Earlier study also found a positive relation between education level and life insurance purchasing behavior, Sarkodie \& Yusif (2015), as similar to the result in the study done by Ofoghi \& Hajipourfarsangi (2013) and Curak, Dzaja \& Pepur (2013). A positive relationship between life insurance and education might also designate that people may have better access to long-term savings and insurance mechanisms that will encourage them to a higher education level, Divya \& Praveen (2012). Aurebach \& Kotlikoff (1989) however found that as the level of education becomes higher, it may reduce the ability of people to buy life insurance. It can be assumed that a higher educated people will prefer to invest in non-life insurance rather than purchasing life insurance policy. Another three studies found that education was not significant in determining life insurance de- mand (see Feyen, Lester \& Rocha, 2013; Nesterova, 2008; Treerattanapun, 2011). The evidence suggests that education is not particularly significant as a promoter for demand of life insurance (Beck, 2003). This is in spite of the fact that knowledge and education is regularly seen as a key indicator of economic and social development.

According to Sarkodie \& Yusif, 2015 the number of family members represent number of dependents in a family. They found that households with fewer with fewer family members have more incentives to buy life insurance products because of more available income compare to persons with higher number family members who tend to spend more of their income for their dependents However, in the research done by $\mathrm{Li}$ (2008), he identified that the number of dependents will also raise the demand for life insurance purchased. As one of the main reasons of taking life insurance is to protect their family against financial loss, we might assume that positive relation can be found between demand for life insurance and number of dependents. Meanwhile, Curak, Dzaja \& Pepur (2013) found that number of dependents is not significant with demand of life insurance

As age increased, household have a higher awareness of the importance and need for life insurance due to increases earning gain, greater number of dependents and also to avoid risk, thus it is a need to have a protection against financial loss. Min Li (2008); Curak, Dzaja \& Pepur (2013) have significantly found that age and demand for life insurance are positively related. As people are getting older, their health status worsen, thus taking life insurance is a good choice to avoid risk of losing financial saving for any medical treatment (if happen). However, Sarkodie \& Yusif (2015) found inverse result and their study was consistent with Chen, Lee \& Wong (2001) that identified a negative relation between these two variables.

\subsection{Economics Factors}

Personal income shows a strong positive relation towards demand for life insurance, while holding other variables constant. The behavior of purchasing life insurance will be higher as income increased. Household has motivation to purchase more as they have greater level of purchasing power because life insurance serves as their income replacement in the event of an unexpected death (Sliwinski et. al. 2013). Dragos (2014) found that income is positively significant for the case of purchasing behavior for life insurance but insignificantly influenced demand for non-life insurance in Asia. The higher the level of income the higher demand for life insurance because it increased households' affordability to purchase, Park \& Lemaire (2012). However, in the other research, they identified negative effect between income and demand for life insurance and this result is consistent with the study by Beck (2003). According to Feyen, Lester \& Rocha (2013), one reason for this is the need of precaution for the potential income of the kids against the premature death of their parent. Enz (2002) however found that higher level of income leads to lower demand for life insurance. The reason is as a household becomes wealthier, they have more abilities to retain risk within their own current financial portfolio. According to Zerria M. et. Al (2017), life insurance demand is positively related with income and financial development. However, other economic variables such as interest rate and inflation have no influence on consumption of life insurance in Tunisia. In the discussion paper by Elisa, Francois \& Mariacristina (2015), they have introduced new variables related to household's financial status; home and stock portfolio ownership. They concluded that financial proximity as a strong factor explaining the willingness to buy life insurance policy in Italy. Their study also found that a simultaneous increase in income and education do not provide a cumulative effect but rather a maximum effect similar to the income shock. Mapharing \& Otuteye (2003), they found very interesting result when they study relations between income and demand for life insurance premium, because 
these two variables are expected to have a long term relationship without any lag period because as people has higher income, they tend to spend more in real time. However, they found that the long term relationship between income and premium is obtained after 3 years lag period. It suggested that people seems to wait and take time to make sure that increment in their income level is permanent before they decide to increase their spending on certain items such as life insurance.

In Malaysia, insurance policy holders are entitled for income tax relief if they purchased life, medical or education insurance. Tax relief is up to RM6,000 per taxpaying individual for life insurance and RM3,000 for medical insurance. Relatively the market for health insurance is big but the awareness among individuals is still low. The marginal tax rate may negatively affect the demand for life insurance, as given that tax deductions increase as higher levels of income earned. In a study done by Nicolas, Jan \& Joachim (2010), found that demand for life insurance increased significantly among the group of household that did not pay taxes on capital returns prior to the tax reform in 2000. They also found that increased in the marginal tax rate by $10 \%$ increased life insurance ownership by $3.3 \%$.

\subsection{Psychographics Factors}

Mukesh (2015) found that psychographic factors have a significant relationship on demand for life insurance. According to the author individual belief $(0.29 \%)$, past experience $(95.22 \%)$, consumer's expectation $(0.55 \%)$ and self-personality traits $(3.94 \%)$ becomes the key factors in influencing consumer behavior towards life insurance purchasing behavior. The study conducted by Sin \& Chee (2017) in Alor Setar found that risk attitude has a significant and negative relationship with the purchase of life insurance because the respondents more likely to be involved in risky behavior and will not seek protection by buying life insurance to cover their personal risk. Annamalah (2013) found that respondents who are risk takers significantly increase the likelihood to purchase life insurance policies. The greater of risk aversion among households, is expected to have a greater incentive to buy life insurance ( $\mathrm{Zhu}$, 2007). Omar (2007) has done a study to identify how consumers respond towards the demand of life insurance in Nigeria. He found that most of Nigerian still do not have any life insurance policy and the main reason for this is because their life is more on believing fate. During the time of emergency, they prefer to ask helps from family, friends and relatives. Lack of trust and confidence towards life insurance company lead to this low rate of life insurance consumption in this country. Leary, Kane, and Woods (2014) examined the factors of a decreasing ownership of life insurance among American household for three different years, 2010, 2012 and 2013. They identified that potential buyers uncertain to buy life insurance is due to lack of trust on insurance agent and insurance company itself. They need trusted agent that can provide them with appropriate financial advice and help them to make a better decision. Sin \& Chee (2017) examined the key determinants of life insurance ownership and identify the factors influence Malaysian to buy life insurance policy by using demographics and psychographics factors. In this study, he found that psychographics factors such as, risk attitude, personal value and trust are just able to explain a small increase in life insurance ownership compared to demographics factors than can explain better.

\subsection{Conceptual Framework}

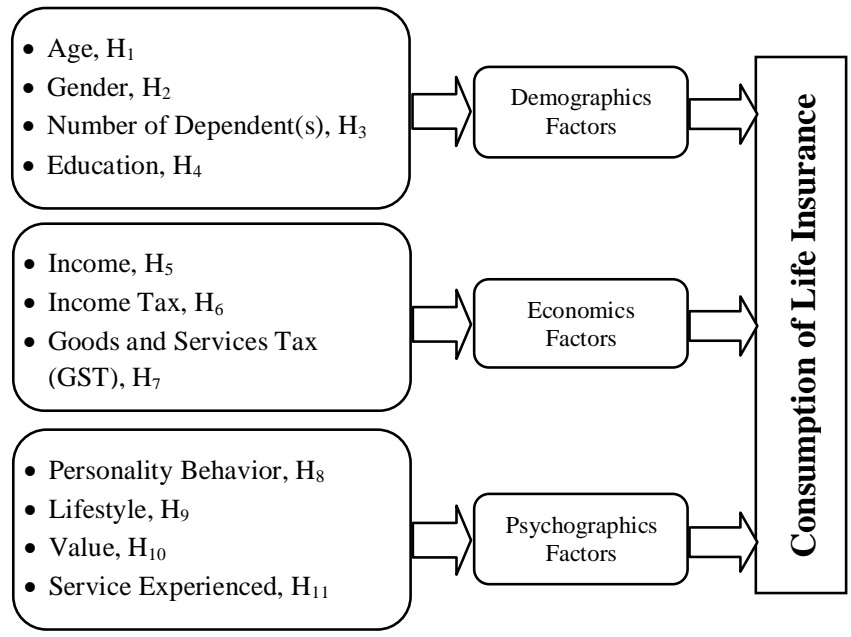

Figure 2.1: Conceptual Framework for Consumption of Life nsurance among School Teachers in Kampar District

\subsection{Hypotheses Development}

In the earlier stage of this research, we developed a total of eleven hypotheses and then omitted one variable (value) due to multicollinearity problem. Therefore, we decided to test out ten hypotheses rather than eleven hypotheses. $\mathbf{H}_{\mathbf{1 0}}$ has been excluded in our study.

\section{Demographics Factors:}

$\mathbf{H}_{1}$ : There is significant effect of age on life insurance consumption among school teachers in Kampar.

$\mathbf{H}_{2}$ : There is significant effect of gender on life insurance consumption among school teachers in Kampar.

$\mathbf{H}_{3}$ : There is significant effect of dependent's number on life insurance consumption among school teachers in Kampar.

$\mathbf{H}_{4}$ : There is significant effect of education on life insurance consumption among school teachers in Kampar.

\section{Economics Factors:}

$\mathbf{H}_{5}$ : There is significant effect of income on life insurance consumption among school teachers in Kampar.

$\mathbf{H}_{6}$ : There is significant effect of income tax on life insurance consumption among school teachers in Kampar.

$\mathbf{H}_{7}$ : There is significant effect of GST on life insurance consumption among school teachers in Kampar.

\section{Psychographics Factors:}

$\mathbf{H}_{\mathbf{8}}$ : There is significant effect of personality behavior on life insurance consumption among school teachers in Kampar.

$\mathbf{H}_{\mathbf{9}}$ : There is significant effect of lifestyle on life insurance consumption among school teachers in Kampar.

$\mathbf{H}_{10}$ : There is significant effect of value on life insurance con sumption among school teachers in Kampar.

$\mathbf{H}_{11}$ : There is significant effect of service experienced on life insurance consumption among school teachers in Kampar.

\section{Methodology}

This study focuses on factors that affecting consumption of life insurance among school teachers in Kampar district, state of Perak, Malaysia. According to the data from Kinta South District Education Office (Pejabat Pendidikan Dearah Kinta Selatan), there is total of 1,256 school teachers currently (July 2016) working in both primary and secondary schools at Kampar district. According to Krejcie and Morgan (1970) the sample size for population of 1,256 is around 294. After taking into consideration about the possibilities of some respondents who might not be re- 
sponding to the survey, we decided to increase the number of sample size to 400 respondents. We were only able to collect 390 questionnaires and there are 377 questionnaires which are usable after the process of filtering. The questionnaires were distributed to 37 schools in Kampar District. There are nine National Secondary Schools, eleven National Primary Schools, thirteen NationalType Primary Schools (Chinese) and four National-Type Primary Schools (Tamil) situated in Kampar district. So, the primary data were collected through self-structured survey questionnaire which were distributed at selected primary and secondary schools. The questionnaire were construct based on 5-points Likert Scale of (1= "Strongly Disagree", 2="Disagree", 3="Neither Agree nor Disagree", 4="Agree", 5="Strongly Agree").

The stratified random sampling technique is applied in order to select the respondent for this study. The justification for selecting this technique is to ensure that all schools in Kampar district have its representative. The data has been analyzed by using Statistical Packages for Social Science (SPSS) program version 16. The multiple linear regression model is designed to test the relationships between consumption of life insurance as the dependent variable and the demographics, economics, and psychographics factors as the explanatory variables.

\subsection{Empirical Model}

The conceptual framework for this study can be described as an empirical model of a functional relationship between determinants (demographics, economics and psychographics) and consumption of life insurance as follows:

Original Model: CLIns. ${ }_{i}=\alpha_{0}+\alpha_{1}$ Age $_{i}+\alpha_{2}$ Gender $_{i}+\alpha_{3}$ Dep $_{. i}+$ $\alpha_{4} \mathrm{Edu}_{. i}+\alpha_{5} \mathrm{I}_{i}+\alpha_{6} \mathrm{IT}_{i}+\alpha_{7} \mathrm{GST}_{i}+\alpha_{8} \mathrm{~PB}_{i}+\alpha_{9} \mathrm{LS}_{i}+\alpha_{10} \mathrm{~V}_{i}+\alpha_{11} \mathrm{SE}_{i}+$ $\varepsilon_{i}$

Revised Model: CLIns ${ }_{i}=\alpha_{0}+\alpha_{1}$ Age $_{i}+\alpha_{2}$ Gender $_{i}+\alpha_{3}$ Dep $_{.}+$ $\alpha_{4} \mathrm{Edu}_{. i}+\alpha_{5} \mathrm{I}_{i}+\alpha_{6} \mathrm{IT}_{i}+\alpha_{7} \mathrm{GST}_{i}+\alpha_{8} \mathrm{~PB}_{i}+\alpha_{9} \mathrm{LS}_{i}+\alpha_{11} \mathrm{SE}_{i}+\varepsilon_{i}$

\begin{tabular}{|l|l|}
\hline Variables & Description \\
\hline CLIns. & Consumption of life insurance \\
\hline Age & Age \\
\hline Gender & Gender \\
\hline Dep. & Number of Dependent(s) \\
\hline Edu. & Education \\
\hline I & Income \\
\hline IT & Income Tax \\
\hline GST & Goods and Services Tax (GST) \\
\hline PB & Personality Behavior \\
\hline LS & Lifestyle \\
\hline V & Value \\
\hline SE & Service Experienced \\
\hline$\varepsilon$ & Error Terms \\
\hline$\alpha$ & The parameter for the explanatory variables \\
\hline
\end{tabular}

\section{Results and Findings}

\subsection{Reliability Test (Cronbach's Statistics)}

The Table 4.1 below shows the reliability test for model variables, whereby the Cronbach's Alpha is 0.870 which is considerable more than minimum alpha value of 0.60 (Hair et al., 2010). Thus, the reliability level for variables is acceptable and can be used for substantive study.

Table 4.1: Cronbach's Alpha Reliability Statistics

\begin{tabular}{|c|c|c|}
\hline \multicolumn{3}{|c|}{ Reliability Statistics } \\
\hline $\begin{array}{c}\text { Cronbach's } \\
\text { Alpha }\end{array}$ & $\begin{array}{c}\text { Cronbach's Alpha Based on } \\
\text { Standardized Items }\end{array}$ & Number of Items \\
\hline 0.870 & 0.849 & 59 \\
\hline
\end{tabular}

\subsection{Descriptive Analysis}

\subsubsection{Demographic Characteristic of Respondent}

This study involved 377 sample cases with $71.6 \%$ are female and 29.4\% are male respondents from National Primary Schools (23.3\%), Chinese National Primary School (25.5\%), Tamil National Primary Schools $(5.0 \%)$ and Secondary National School (46.2\%). From the data collection, we found that around $72.1 \%$ respondents have at least one insurance policy while $27.9 \%$ respondents do not have any insurance policy yet. $39.8 \%$ are within age group of 31 - 40 years old, different ethnics; Malay (55.4\%), Chinese $(32.9 \%)$, Indian $(9.8 \%)$ and others $(1.9 \%)$. Three quarters $(74.8 \%)$ of respondents are married and around $66.2 \%$ of them have less than three dependents in their family. $76.9 \%$ out of 377 respondents obtained Bachelor Degree as the highest education level. In terms of family income, most of them having income within RM4,001 - RM5,000, that consists of $35.1 \%$ compared to other levels of income. Table 4.2 summarizes the demographic characteristic of respondents.

Table 4.2: Descriptive Statistic for Demographic Characteristic of Respondent

\begin{tabular}{|c|c|c|c|}
\hline $\begin{array}{c}\text { Categorical Vari- } \\
\text { ables }\end{array}$ & Attributes & Frequency & $\begin{array}{c}\text { Percentage } \\
(\%)\end{array}$ \\
\hline \multirow[t]{2}{*}{ Gender } & Male & 111 & 29.4 \\
\hline & Female & 266 & 71.6 \\
\hline \multirow[t]{5}{*}{ Age } & $<20$ years & 2 & 0.5 \\
\hline & $21-30$ years & 82 & 21.8 \\
\hline & $31-40$ years & 150 & 39.8 \\
\hline & $41-50$ years & 90 & 23.9 \\
\hline & $>50$ years & 53 & 14.1 \\
\hline \multirow[t]{4}{*}{ Ethnicity } & Malay & 209 & 55.4 \\
\hline & Chinese & 124 & 32.9 \\
\hline & Indian & 37 & 9.8 \\
\hline & Others & 7 & 1.9 \\
\hline \multirow[t]{4}{*}{ Marital Status } & Single & 88 & 23.4 \\
\hline & Married & 282 & 74.8 \\
\hline & Divorced & 5 & 1.3 \\
\hline & Widowed & 2 & 0.5 \\
\hline \multirow{4}{*}{$\begin{array}{l}\text { Number of De- } \\
\text { pendent(s) }\end{array}$} & $0-3$ & 250 & 66.2 \\
\hline & $4-6$ & 116 & 30.8 \\
\hline & $7-9$ & 10 & 2.7 \\
\hline & $>20$ & 1 & 0.3 \\
\hline \multirow[t]{5}{*}{ Education Level } & Sijil Perguruan & 20 & 5.3 \\
\hline & $\begin{array}{l}\text { STPM / Foundation/ } \\
\text { Diploma }\end{array}$ & 27 & 7.2 \\
\hline & Bachelor Degree & 290 & 76.9 \\
\hline & Master Degree & 39 & 10.3 \\
\hline & $\mathrm{PhD}$ & 1 & 0.3 \\
\hline \multirow{4}{*}{$\begin{array}{l}\text { Monthly Family } \\
\text { Income }\end{array}$} & RM2501 - RM4000 & 111 & 29.4 \\
\hline & RM4001 - RM5500 & 132 & 35.1 \\
\hline & RM5501 - RM7000 & 74 & 19.6 \\
\hline & $>$ RM7001 & 60 & 15.9 \\
\hline \multirow[t]{4}{*}{$\begin{array}{l}\text { School Classifi- } \\
\text { cation* }\end{array}$} & $\begin{array}{ll}\text { National } & \text { Primary } \\
\text { School (11) } & \end{array}$ & 88 & 23.3 \\
\hline & $\begin{array}{l}\text { National } \begin{array}{l}\text { Primary } \\
\text { School }- \text { Chinese } \\
(13)\end{array} \\
\end{array}$ & 96 & 25.5 \\
\hline & $\begin{array}{l}\text { National Primary } \\
\text { School - Tamil (4) }\end{array}$ & 19 & 5.0 \\
\hline & $\begin{array}{l}\text { National Secondary } \\
\text { School (9) }\end{array}$ & 174 & 46.2 \\
\hline \multirow{2}{*}{$\begin{array}{l}\text { Holder of Life } \\
\text { Insurance Policy }\end{array}$} & Yes & 272 & 72.1 \\
\hline & No & 105 & 27.9 \\
\hline
\end{tabular}

* Refer to APPENDIX I

Sources: Authors Calculation

\subsubsection{Analysis of Insured Respondent}

Figure 4.1 until 4.8 summarizes the demographic characteristic of insured respondents. Total number of 272 respondents already have at least 1 insurance policy consist of $27.9 \%$ of male and $72.1 \%$ are female, and there are those who yet to buy the life in- 
surance policy which are $33.3 \%$ male and $66.7 \%$ female respectively. Based on the age group, the highest percentage of teachers with life insurance policy belongs to age group within 31 to 40 years old, consist of $41.2 \%$ compared to others age group, and for those with no insurance policy also from the same age group, with $36.2 \%$ within 31 to 40 years old. In terms of ethnicity, Malay teachers with life insurance policy consist of 136 , following by Chinese (107), Indian (25) and others (4). The highest purchaser of life insurance policy is in married status (206) and the respondents with three numbers of dependents have higher (64.7\%) tendency to purchase life insurance policy compared to those with more than seven numbers of dependents $(1.9 \%)$. Based on education level, teachers with bachelor degree holders have the highest propensity to buy life insurance policy consists of $77.2 \%$ compared to others with higher or lower education level. Respondents with family income between RM4,001 to RM5,500 shows the highest percentage in buying life insurance policy (37.1\%). Out of 37 schools in Kampar district, there are two schools showing the lowest percentage on purchasing life insurance policy compared to other schools, which is SK Kuala Dipang (37.5\%) and SK Air Hitam Labu, Tronoh Mines (33.3\%).
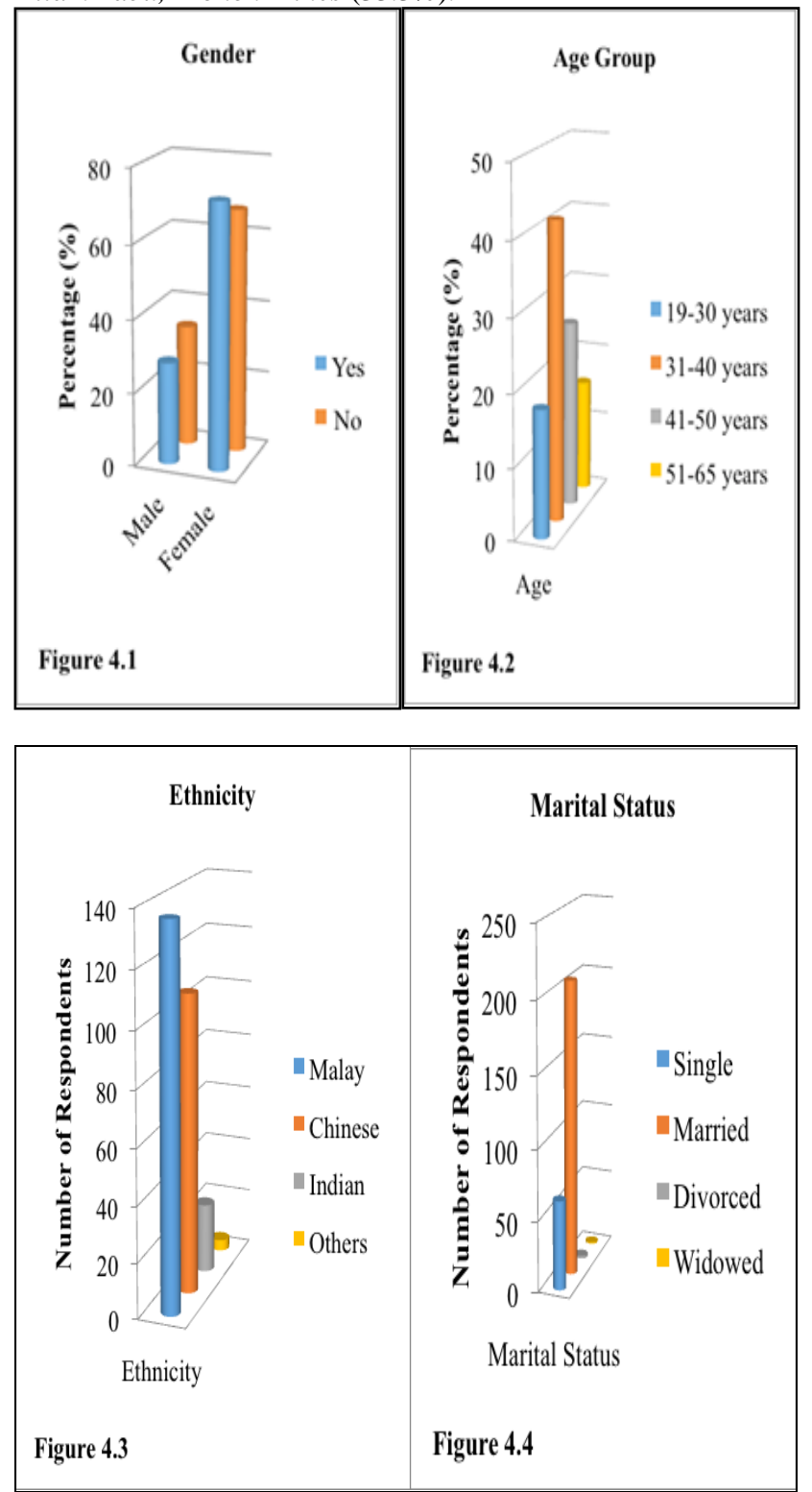

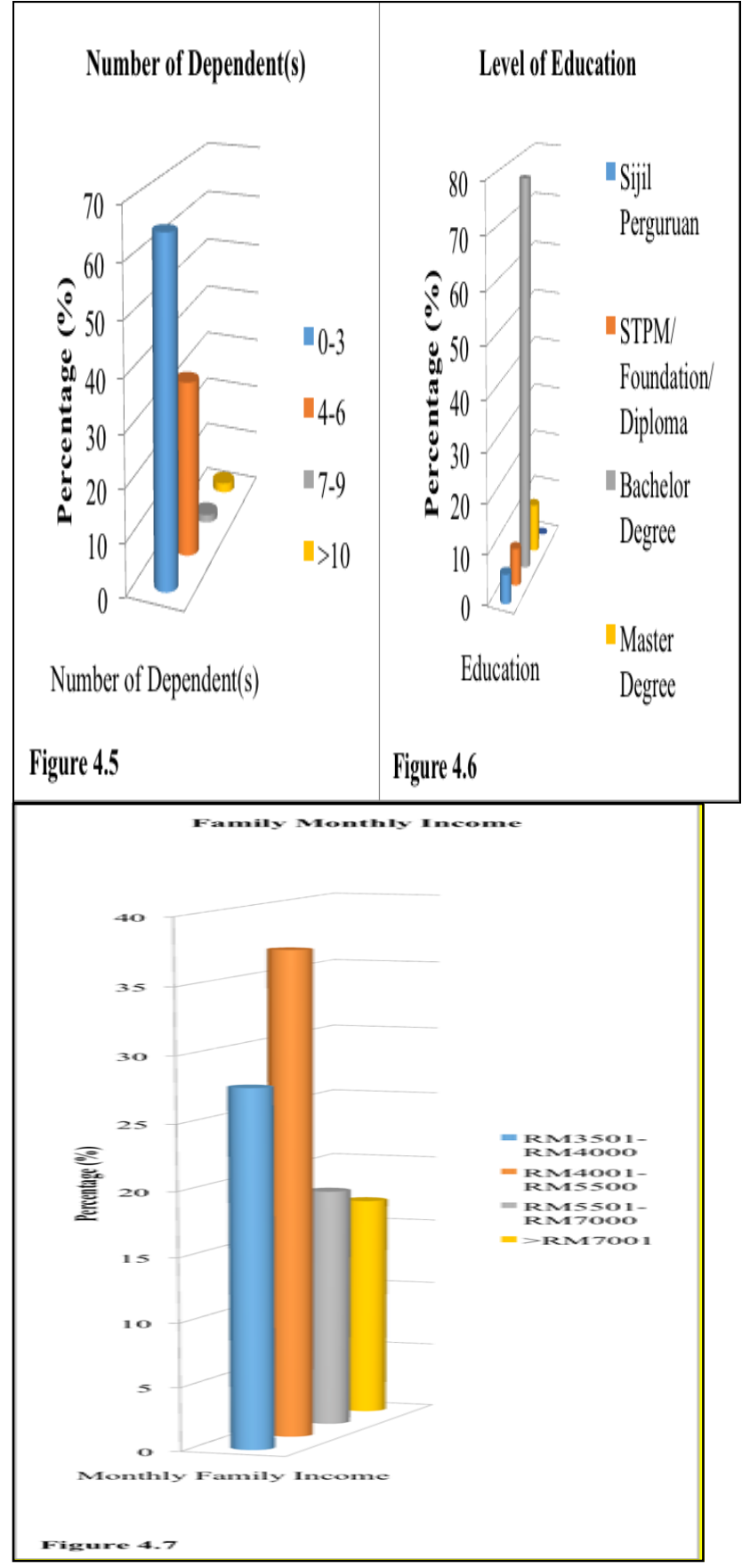




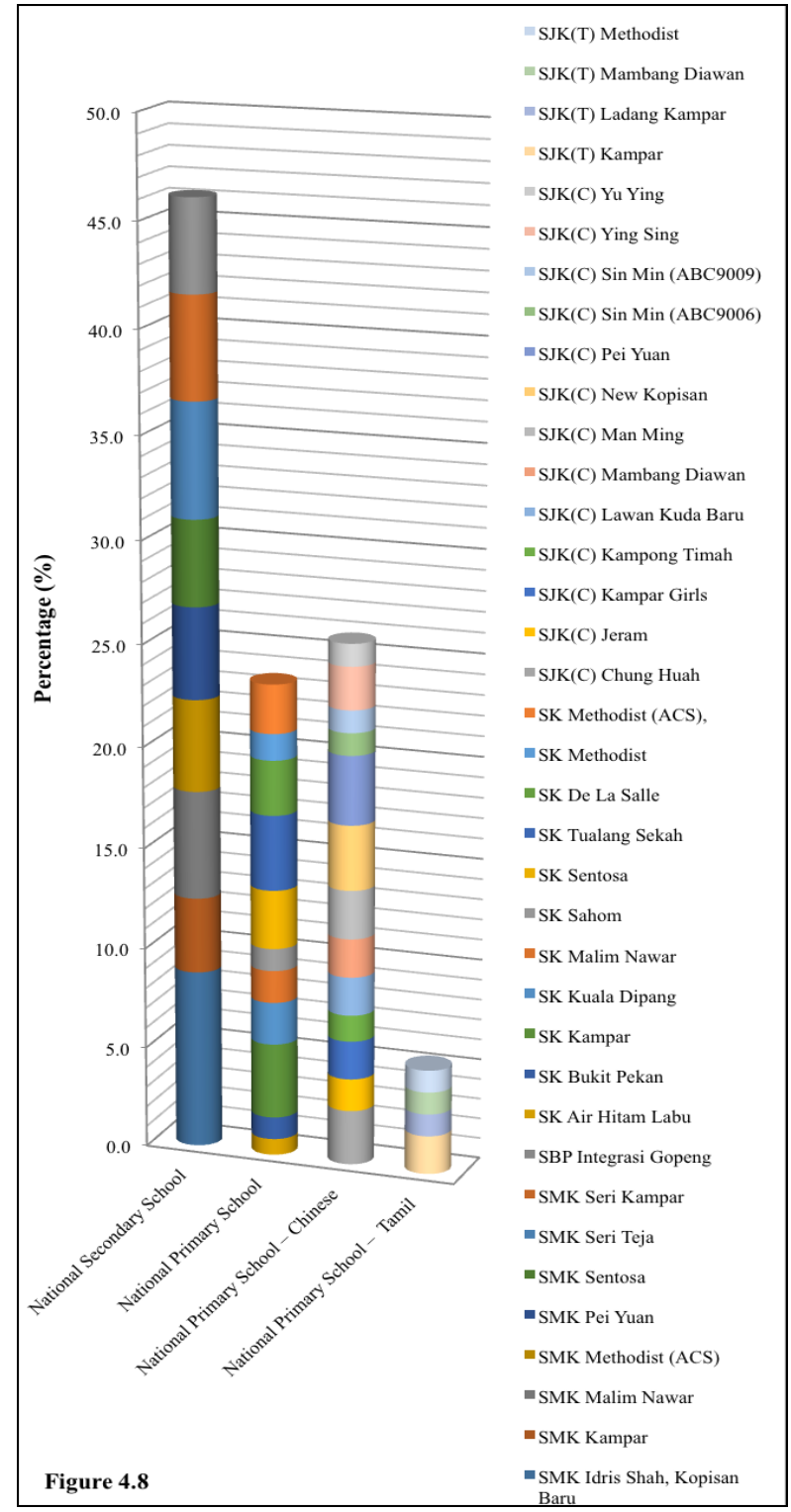

\subsection{Inferential Analysis}

\subsubsection{Multicollinearity}

Multicollinearity problem occurs in our analysis when two variables in model are very highly correlated (more than $10.0 \mathrm{VIF}$ ) with one another which are personality behavior and value as shown in Table 4.3(a).

Table 4.3(a): Collinearity Statistics (Before)

\begin{tabular}{|c|c|c|}
\hline \multirow{2}{*}{ Variables } & \multicolumn{2}{|c|}{ Collinearity Statistics } \\
\cline { 2 - 3 } & Tolerance & VIF \\
\hline Personality Behavior & 0.000 & 6747.395 \\
\hline Value & 0.000 & 6745.291 \\
\hline
\end{tabular}

Sources: Authors Calculation

As stated in the conceptual framework (Figure 2.1), the two factors in Psychographics which are value and personality behavior show multicollinearity. Therefore, we decided to exclude either one variable in order to solve this problem. The multicollinearity problem solved after the removal of the "value" variable from the model. Table 4.3(b) shows the VIF results after excluding the variable "value".
Table 4.3(b): Collinearity Statistics (After)

\begin{tabular}{|c|c|c|}
\hline \multirow{2}{*}{ Variables } & \multicolumn{2}{|c|}{ Collinearity Statistics } \\
\cline { 2 - 3 } & Tolerance & VIF \\
\hline Personality Behavior & 0.230 & 4.351 \\
\hline
\end{tabular}

\subsubsection{Multiple Linear Regression Analysis}

A set of independent variables is constructed to explain the dependent variables through the test of model significant and Rsquared. Overall the model constructed for testing the factors of determinant of life insurance consumption show statistically significant relationship between all independent variables and dependent variables at $1 \%$ significant level. However, the R-squared did not favour to this model because it is less than $40 \%(0.4)$ which is $0.23(23 \%)$. The R-squared of this study is low to moderate, the result of R-squared still acceptable for Social Sciences context. It also explains that there are other factors which is not been tested in our research would contribute to the teachers' decision in purchasing life insurance policy.

$$
\begin{aligned}
\text { CLIns. }= & 10.931+4.736 \mathrm{Age}-3.402 \mathrm{Gender}- \\
& 0.052 \mathrm{Dep} .+0.018 \mathrm{Edu} .+0.010 \mathrm{I}-0.022 \mathrm{IT} \\
& -0.015 \mathrm{GST}+1.010 \mathrm{~PB}-0.027 \mathrm{LS}- \\
& 0.013 \mathrm{SE}
\end{aligned}
$$

Table 4.4 shows the coefficients of the model for ten independent variables. Among the variables, only personality behaviour is significant and positive in this model. As we can see through the result, age, education, and income level are not significant but positively related to consumption of life insurance. Meanwhile, gender, number of dependent(s), income tax, GST, lifestyle and service experienced are not significant but negatively related to consumption of life insurance.

Table 4.4: Coefficients

\begin{tabular}{|c|c|c|c|c|c|}
\hline \multirow{2}{*}{ Model } & \multicolumn{2}{|c|}{$\begin{array}{c}\text { Unstandardized } \\
\text { Coefficients }\end{array}$} & $\begin{array}{c}\text { Standardized } \\
\text { Coefficients }\end{array}$ & \multirow{2}{*}{$\mathrm{t}$} & \multirow{2}{*}{ Sig. } \\
\cline { 2 - 4 } & $\mathrm{B}$ & $\begin{array}{c}\text { Std. } \\
\text { Error }\end{array}$ & Beta & & \\
\hline (Constant) & 10.931 & 45.032 & & 0.243 & 0.808 \\
\hline Age & 4.736 & 11.767 & 0.024 & 0.402 & 0.688 \\
\hline Gender & -3.402 & 9.409 & -0.022 & -0.362 & 0.718 \\
\hline $\begin{array}{c}\text { Number of } \\
\text { Dependent(s) }\end{array}$ & -0.052 & 0.452 & -0.014 & -0.116 & 0.908 \\
\hline Education & 0.018 & 0.335 & 0.006 & 0.053 & 0.958 \\
\hline Income & 0.010 & 0.238 & 0.003 & 0.042 & 0.966 \\
\hline Income Tax & -0.022 & 0.090 & -0.017 & -0.244 & 0.807 \\
\hline GST & -0.015 & 0.224 & -0.004 & -0.065 & 0.948 \\
\hline $\begin{array}{c}\text { Personality } \\
\text { Behavior }\end{array}$ & $1.010 * * *$ & 0.233 & 0.491 & 4.329 & 0.000 \\
\hline Lifestyle & -0.027 & 0.205 & -0.015 & -0.134 & 0.894 \\
\hline $\begin{array}{c}\text { Service Expe- } \\
\text { rienced }\end{array}$ & -0.013 & 0.058 & -0.013 & -0.234 & 0.815 \\
\hline
\end{tabular}

Note: $* * *$ significant at the $1 \%$ level

Sources: Authors Calculation

\subsubsection{Relative weightages of Demographics Factors, Econom-} ics Factors and Psychographics Factors

A relative weight for each dimension can be calculated from the unstandardized coefficients presented in Table 4.5.

Relative weight of the dimensions $\mathrm{i}=\frac{\beta_{i}}{\sum_{1}^{k} \beta_{j}}$ 


\begin{tabular}{|c|c|c|c|c|}
\hline 离 芯 & Attributes & $\begin{array}{l}\text { Unstandard- } \\
\text { ized Beta }\end{array}$ & $\mid$ Beta $\mid$ & $\begin{array}{l}\text { Percent- } \\
\text { age } \\
\text { Weight } \\
(\%)\end{array}$ \\
\hline \multirow{4}{*}{ 品 } & Age & 4.736 & 4.736 & $\mathbf{5 7 . 7 0}$ \\
\hline & Gender & -3.402 & 3.402 & 41.45 \\
\hline & $\begin{array}{l}\text { Number of De- } \\
\text { pendent(s) }\end{array}$ & -0.052 & 0.052 & 0.63 \\
\hline & Education & 0.018 & 0.018 & 0.22 \\
\hline \multirow{3}{*}{ 方 } & Income & 0.010 & 0.010 & 21.28 \\
\hline & Income Tax & -0.022 & 0.022 & 46.81 \\
\hline & GST & -0.015 & 0.015 & 31.91 \\
\hline \multirow{3}{*}{ 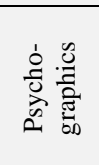 } & $\begin{array}{l}\text { Personality } \\
\text { Behavior }\end{array}$ & 1.010 & 1.010 & 96.19 \\
\hline & Lifestyle & -0.027 & 0.027 & 2.57 \\
\hline & $\begin{array}{l}\text { Service Experi- } \\
\text { enced }\end{array}$ & -0.013 & 0.013 & 1.24 \\
\hline
\end{tabular}

Sources: Authors Calculation

Table 4.5 shows relative weight of the Demographics factors viz. Age, Gender, Number of Dependent(s) and Education; Economics factor viz. Income, Income Tax and GST; Psychographic factors viz. Personality Behavior, Lifestyle and Service Experienced. Our calculations of weighted percentage are based on its own determinants. The importance was given to the attribute "age" $(57.70 \%)$ on demographics factors. Age is one of the factors that influence respondents (teachers) in Kampar District to purchase life insurance policy because the awareness among respondents as life has full of uncertainty and need to protect their next kin against financial loss. Based on economics factors, income tax (46.81\%) contributes the highest weightage compare to others. It is because the respondents able to get tax exempted and able to reduce taxable income if they (teachers) purchased life insurance policy. The dimension "personality behavior" $(96.19 \%)$ have highest impact on psychographics factors. The reason of this result is the respondents (teachers) have high tendency to be influenced by their family, peers, social media and also the needs to protect their dependents (Irfan et al., 2017).

\subsubsection{Correlation and Hypothesis Testing}

In order to analyze the strength of the correlation among various variables, we use Spearman regression linear at 2-tailed significant level. In this regression, the positive sign indicates perfect positive correlations while the negative sign indicates otherwise. The value closer to \pm 1 indicates the linear relationship between variables. Most of our hypotheses are supported at $1 \%$ significant level as presented in Table 5.

\begin{tabular}{|c|c|c|c|c|c|c|c|c|c|c|c|}
\hline 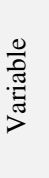 & 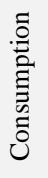 & 䊝 & $\begin{array}{l}\bar{v} \\
\bar{v} \\
\stackrel{0}{0}\end{array}$ & 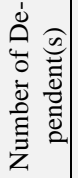 & 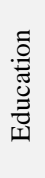 & 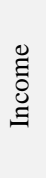 & 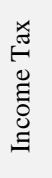 & $\sqrt{5}$ & 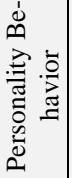 & 离 & 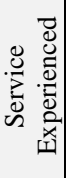 \\
\hline$\underset{\infty}{\infty}$ & 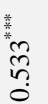 & $\stackrel{8}{8}$ & & & & & & & & & \\
\hline 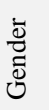 & $\begin{array}{l}\text { 丵 } \\
\text { ñ } \\
\text { ñ }\end{array}$ & 蒾 & §. & & & & & & & & \\
\hline
\end{tabular}

\begin{tabular}{|c|c|c|c|c|c|c|c|c|c|c|c|}
\hline 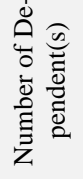 & 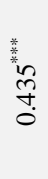 & 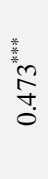 & 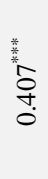 & ه్రి & & & & & & & \\
\hline 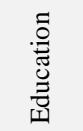 & సֶ. & 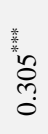 & 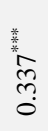 & 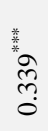 & $\underset{-}{8}$ & & & & & & \\
\hline 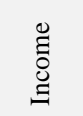 & 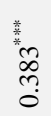 & 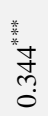 & 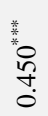 & 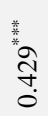 & $\stackrel{\text { 章 }}{\stackrel{5}{0}}$ & $\underset{-}{8}$ & & & & & \\
\hline 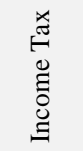 & 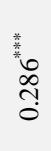 & 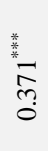 & $\frac{\sqrt[*]{*}}{2} \stackrel{2}{\circ}$ & 昚 & 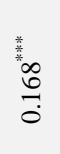 & 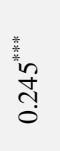 & $\underset{-}{8}$ & & & & \\
\hline 包 & ô. & ô. & $\frac{\text { *0.0 }}{\stackrel{n}{0}}$ & $\begin{array}{l}\stackrel{0}{\circ} \\
\stackrel{0}{0}\end{array}$ & 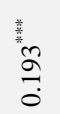 & $\begin{array}{l}\text { 蔁 } \\
\infty \\
\infty \\
1 \\
0\end{array}$ & $\frac{\text { 亲 }}{\infty}$ & $\stackrel{8}{8}$ & & & \\
\hline 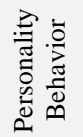 & స్ & $\begin{array}{l}\stackrel{*}{*} \\
\stackrel{n}{0} \\
0\end{array}$ & $\frac{\stackrel{*}{*}}{\stackrel{m}{m}}$ & $\stackrel{\text { *. }}{\stackrel{*}{*}}$ & 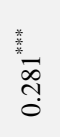 & 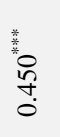 & $\frac{\text { * }}{\stackrel{J}{+}}$ & 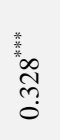 & $\stackrel{8}{\&}$ & & \\
\hline $\begin{array}{l}\frac{0}{3} \\
\stackrel{0}{0} \\
: 3\end{array}$ & $\begin{array}{l}\stackrel{0}{0} \\
\dot{0}\end{array}$ & ֻே & $\frac{{ }^{*}}{3}$ & $\stackrel{\vec{n}}{\circ}$ & $\frac{\sqrt{3}}{\frac{1}{2}}$ & 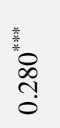 & $\stackrel{\hat{S}}{0}$ & 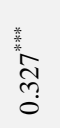 & \begin{tabular}{l} 
丵 \\
\multirow{5}{*}{} \\
0 \\
0
\end{tabular} & $\underset{-}{8}$ & \\
\hline 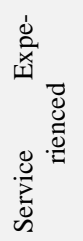 & חె & 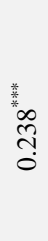 & 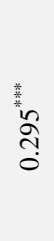 & $\stackrel{\sqrt[*]{*}}{\sqrt{*}}$ & 旁 & 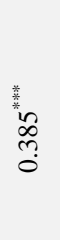 & 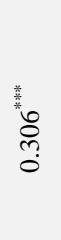 & 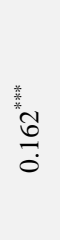 & 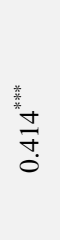 & 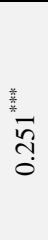 & $\stackrel{8}{8}$ \\
\hline
\end{tabular}

Sources: Authors Calculation

\subsubsection{Significant Effect of Age on Life Insurance Consump- tion $\left(\mathrm{H}_{1}\right)$}

Based on Table 4.6 above, there is a correlation between the age and life insurance consumption among school teachers significant at $1 \%$. The correlation coefficient of these two variables is 0.533 and it is positively correlated with each other. Therefore, our result supported the hypothesis. This result is consistent with the previous study done by Min Li (2008); Truett \& Truett (2014) and Marijana, Ivana \& Sandra (2015).

\subsubsection{Significant Effect of Gender on Life Insurance Con- sumption $\left(\mathbf{H}_{2}\right)$}

Gender factor positively correlated with dependent variable at $1 \%$ significant level. Therefore, the result supported our hypothesis. 


\subsubsection{Significant Effect of Dependent's Number on Life In- surance Consumption $\left(\mathbf{H}_{3}\right)$}

Number of dependent(s) is one of the determinants that increase the consumption of life insurance among school teachers in Kampar district. The analyses result shows dependent and independent variable are correlated positively $(0.435)$ and significant at degree of $1 \%$. Therefore, the result supports the hypothesis. Consistent with research done by Min $\mathrm{Li}$ (2008), he also identified that the increase in the number of dependents will also raise the demand for life insurance purchased.

\subsubsection{Significant Effect of Education on Life Insurance Con- sumption $\left(\mathrm{H}_{4}\right)$}

The result of education factor in Table 5 , shows significant at the degree of $1 \%$ and positively correlated with dependent variable. The correlation coefficient of these two variables is 0.277 , thus our result supported this hypothesis. The similar result has been found by Sarkodie \& Yusif (2015); Ofoghi \& Farsangi (2013); Curak, Dzaja \& Pepur (2013) and Divya \& Praveen (2012).

\subsubsection{Significant Effect of Income on Life Insurance Con- sumption $\left(\mathbf{H}_{5}\right)$}

Income factor shows positive relationship and significant at $1 \%$ on consumption of life insurance among school teachers in Kampar. Therefore, the result supported our hypothesis and the finding similar with previous study by Adam, Tomasz \& Malgorzata (2013); Simona (2014) and Park \& Lemaire (2011a).

\subsubsection{Significant Effect of Income Tax on Life Insurance Consumption $\left(\mathbf{H}_{6}\right)$}

The correlation coefficient of income tax and life insurance consumption is 0.286 . Using $1 \%$ degree of significant, the result shows the positive relation between these two variables. Therefore, our result supported this hypothesis. In the study done by Nicolas, Jan \& Joachim (2010), they also found that demand for life insurance increased significantly among the group of household.

\subsubsection{Significant Effect of GST on Life Insurance Consump- tion $\left(\mathbf{H}_{7}\right)$}

The result for GST and consumption of life insurance in Table 5 , shows that dependent and independent variable positively correlated but not significant. Therefore, our hypotheses do not support of these two variables.

\subsubsection{Significant Effect of Personality Behavior on Life In- surance Consumption $\left(\mathrm{H}_{8}\right)$}

The personality behavior is one reliable factor that related to the dependent variable of our research as this variable becomes the most important factor in influencing the consumption of life insurance among school teachers in Kampar (refer to Table 4). The correlation coefficient of personality behavior and life insurance consumption is 0.239 , positively related and also significant at $1 \%$ level. Therefore, our result supported hypothesis and it is similar with the findings by Mukesh (2015).

\subsubsection{Significant Effect of Lifestyle on Life Insurance Con- sumption $\left(\mathbf{H}_{9}\right)$}

The lifestyle variable is negatively related and insignificant with dependent variable (consumption of life insurance) at -0.069 . Our hypothesis not supported these two variables. Tan \& Lim (2017) also found negative relationship but their result was significant.

\subsubsection{Significant Effect of Service Experienced on Life In-} surance Consumption $\left(\mathrm{H}_{11}\right)$

Based on the result in Table 5, service experienced variable correlated positively with the consumption of life insurance and significant at the level of $1 \%$, so the result supported our hypothesis.

\section{Conclusion and Recommendations}

\subsection{Conclusion}

In this paper we have analyzed the determinants of life insurance consumption among school teachers in Kampar district. In the multiple regression model, only personality behavior in psychographics factor is significant at level of $1 \%$, compared to other variables that influenced teacher's decision to purchase life insurance policy.

The independent variable not only correlated with dependent variable but it also shown the correlation within independent variables. The correlation in demographics factors show age, gender number of dependent(s) and education variable positively significant and correlated each other at $1 \%$. Moreover, the correlation in economics factors show that income, income tax and GST variable are positively correlated to each other at $1 \%$ significant level. Furthermore, the correlation among personality behavior, lifestyle and service experience in psychographics factors show positive relationship to each other at $1 \%$ significant level. Overall, the individual independent variables of demographics factors are significant on life insurance consumption. On the other hand, only GST variable in economics factors and lifestyle in psychographics factors insignificant on life insurance consumption, the rest of independent variables are significant.

The individual variable of age shows positive relationship on gender, number of dependent(s), education, income, income tax and service experience which significant at $1 \%$; personality behavior significant (5\%) but GST and lifestyle are insignificant. The gender variable shows positive relationship with the number of dependents, education, income, income tax, personality behavior, lifestyle and service experience which significant at $1 \%$, while GST significant at 5\%. Meanwhile, there are positive relationship between education, income, income tax, personality behavior and service experienced (1\% significant); GST and lifestyle (insignificant) on the number of dependent(s). Education and income associate positively with income tax, GST, personality behavior, lifestyle and service experience at $1 \%$ significant level. Income tax shows positive relationship with GST and service experience at significant level of $1 \%$; personality behavior significant $(5 \%)$ but lifestyle is insignificant. GST and personality behavior have positive correlation and significant at $1 \%$ with lifestyle and service experience. Last but not least, lifestyle and service experience are positively related to each other at significant level $1 \%$.

In conclusion, personality behavior becomes a reliable factor in psychographics determinants to influence consumption of life insurance among school teachers in Kampar district. Therefore, our results of personality behavior show positive, significant and highly weighted factor on life insurance consumption.

\subsection{Recommendations}

There is a need to develop appropriate insurance products and encourage new delivery channels to reach out to the remainder $45 \%$ of the population, at which a high ratio could be focused on rural areas. The insurance company need to test and explore smart technologies that will benefit their customer to make it easier and Convenient to access. Clients could gain benefit If there is an improvement in providing services such as solutions and payment of 
claims trough the development of technology. While most consumers still prefer to use traditional distribution channel such as insurance agent, insurance company should explore new way of solution with continue experimental innovation that will attract more customers in future.

Currently, the life insurance industry has around 85,000 agents and 20,000 bank executives registered with LIAM. In the next few years, the advancement in internet usage, mobile devices and social networking may change the method of connection among consumers, interaction and transaction in businesses. With the huge improvement and usage of mobile phones and the internet access, there is a need to discover potentials of adding these to a company's multi-channel delivery of insurance. It is also significant to guarantee that the products sold are based on the needs of the consumers. In addition, the representatives of the insurance company (agents) should provide proper advice to their clients so that they can make an informed decision of the insurance plan that they plan to purchase.

Currently, tax relief for premium paid on medical and an education policy are combined and eligible only for RM3,000 and this amount is of course not enough to cover both healthcare and education together. The government should raise the tax relief to at least RM6,000 or else the current combined tax relief of RM6,000 for Employees Provident Fund (EPF) and life insurance can be separated. The savings in EPF is to meet retirement needs in future, however life insurance will meet the immediate needs of the family as their income replacement in the event of an unexpected death or unfortunate thinks happen. Therefore, it would be beneficial to the citizen if they have RM6,000 for tax relief of EPF contributions and another RM6,000 reliefs for life insurance and takaful premiums.

\section{Acknowledgement}

This research work (Project Number: IPSR/RMC/UTARRF/2016C2/J01) supported by UTAR Research Fund 2016 Cycle 2 (UTARRF). We also would like to thank Pejabat Pendidikan Daerah Kinta Selatan, headmasters and school teachers in Kampar District.

\section{References}

[1] Annamalah S. Profiling and Purchasing Decision of Life Insurance Policies among Married Couples in Malaysia. World Applied Sciences Journal. 2013;23(3):296-304

[2] Beck T, Webb I. Economic, demographic, and institutional determinants of life insurance consumption across countries. The World Bank Economic Review. 2003 Jun 1;17(1):51-88 http://doi.org/10.1093/wber/lhg011

[3] Chen R, Wong KA, Lee HC. Age, period, and cohort effects on life insurance purchases in the US. Journal of Risk and Insurance. 2001 Jun 1:303-27.

[4] Dzaja I. The effect of social and demographic factors on life insurance demand in Croatia. International Journal of Business and Social Science. 2013 Aug 1;4(9).

[5] Negi D, Singh P. Demographic analysis of factors influencing purchase of life insurance products in india. European Journal of Business and Management. 2012;4(7):169-80.

[6] Dragos SL. Life and non-life insurance demand: the different effects of influence factors in emerging countries from Europe and Asia. Economic research-Ekonomska istraživanja. 2014 Jan 1;27(1):169-80. http://doi.org/10.1080/1331677X.2014.952112

[7] Enz R. The S-curve relation between per-capita income and insurance penetration. The Geneva Papers on Risk and Insurance-Issues and Practice. 2000 Jul 1;25(3):396-406.

[8] Feyen E, Lester R, Rocha R. What drives the development of the insurance sector? An empirical analysis based on a panel of developed and developing countries.
[9] Irfan, A., Rasli, A., Sami, A., \& Liaquat, H. (2017). Role of Social Media in Promoting Education Tourism. Advanced Science Letters, 23(9), 8728-8731.

[10] Krejcie RV, Morgan DW. Determining sample size for research activities. Educational and psychological measurement. 1970 Sep;30(3):607-10. http://doi.org/10.1177/001316447003000308

[11] Leary P, Kane KM, Woods DF. Reversing the Decline in Life Insurance Ownership. Journal of Financial Service Professionals. 2014 Jul 1;68(4)

[12] Li M. Factors influencing households' demand for life insurance. University of Missouri-Columbia; 2008.

[13] Luciano E, Outreville JF, Rossi M. Life insurance demand: evidence from Italian households; a micro-economic view and gender issue.

[14] Mapharing M, Otuteye E. Determinants of demand for life insurance: The case of Canada. Journal of Comparative International Management. 2015;18(2):1

[15] Mukesh, S. Life Insurance Consumer Psychographics and Its Relationship with Satisfaction. International Journal in Management and Social Science. 2015 July; 3(4), 124-131.

[16] Nesterova D. Determinants of the demand for life insurance: Evidence from selected CIS and CEE countries. National University "Kyiv-Mohyla Academy" Master's Program in Economics. 2008.

[17] Ofoghi R, Farsangi RH. the effect of insurance knowledge on the insurance demand. The case study of auto insurance. Technical Journal of Engineering and Applied Sciences. 2013;3(23):3356-64.

[18] Omar OE. The retailing of life insurance in Nigeria: an assessment of consumers' attitudes. The Journal of Retail Marketing Management Research. 2007.

[19] Outreville JF. Risk aversion, risk behavior, and demand for insurance: A survey. Journal of Insurance Issues. 2014 Oct 1:158-86.

[20] Park SC, Lemaire J. The impact of culture on the demand for nonlife insurance. ASTIN Bulletin: The Journal of the IAA. 2012 Nov;42(2):501-27

[21] Sarkodie EE, Yusif HM. Determinants of Life Insurance Demand, Consumer Perspective-A Case Study of Ayeduase-Kumasi Community, Ghana.

[22] Sauter N, Walliser J, Winter J. Tax incentives, bequest motives, and the demand for life insurance: evidence from a natural experiment in Germany. Journal of Pension Economics \& Finance. 2015 Oct;14(4):525-53.

[23] Sin TS, Chee LC. The Relationship of Life Insurance Ownership with Demographic and Psychographic Factors: A Preliminary Study in Alor Setar, Kedah.

[24] Sliwinski A, Michalski T, Roszkiewicz M. Demand for life insurance-An empirical analysis in the case of Poland. The Geneva Papers on Risk and Insurance-Issues and Practice. 2013 Jan 1;38(1):62-87.

[25] Zerriaa M, Amiri MM, Noubbigh H, Naoui K. Determinants of Life Insurance Demand in Tunisia. African Development Review. 2017 Mar 1;29(1):69-80.

[26] Zerriaa M, Amiri MM, Noubbigh H, Naoui K. Determinants of Life Insurance Demand in Tunisia. African Development Review. 2017 Mar 1;29(1):69-80

[27] Zhu Y. One- Period Model of Individual Consumption, Life Insurance, and Investment Decisions. Journal of Risk and Insurance. 2007 Sep 1;74(3):613-36 